\title{
MAFIA IN THE ITALIAN PENAL CODE
}

\author{
Cezariusz Sońta
}

Wojskowa Akademia Techniczna

\author{
Joanna Brylak \\ Europejska Wyższa Szkoła Prawa i Administracji
}

\begin{abstract}
In security sciences organized crime starts to be treated as an asymmetric hazard. Organized crime covers, in the opinion of the Authors, all crimes committed within the criminal structures that are characterized by organization. Mafia is, on the one hand, a proper name for a Sicillian criminal organization, which has been used in the sense at least since the 19th century. On the other hand, it also means any criminal organization of mafia nature. In the Polish law, like in most legislations, the notion of mafia is not present. The authors try, however, to create its non-legal definition. They draw attention to the fact that the Penal Code of the Republic of Italy contains an original solution - apart from an "ordinary" criminal association (Article 416) it introduces penality for participation in an association of mafia nature (Article 416 bis). The primary purpose of this study is to analyse this structure in comparison to the origin and solution of the Italian antimafia law.
\end{abstract}

Keywords: mafia, criminal organizations, Italian Penal Code, organized crime.

\section{The notions of organized crime and mafia}

In security sciences organized crime starts to be treated, from the point of view of national security, as an asymmetric hazard ${ }^{1}$ Organized crime is undoubtedly a significant threat to public order and internal security of the state. A destructive impact of a criminal organization on national security seems to be possible only exceptionally, in the case of a completely atypical weakness of state structures, gradually pushed away by a criminal organization as it was in Columbia in the period of the highest intensity of activity of the so-called drug cartels of P. Escobar. On the other hand, a hazard from criminal structures in the mentioned spheres certainly increases along with the growth in their numbers, organizational levels, income and degree of infiltration of state structures.

Most legislations do not define organized crime, although many of them use this notion. The attempts to define it were, on the other hand, undertaken many

1 This fact was pointed out by for instance by C. Sońta, Ugrupowania przestępcze $z$ art. 258 k.k. jako wyznacznik zorganizowanej przestępczości, in: (ed.:) R. Jakubczak, R. Radziejewski, Terroryzm a bezpieczeństwo państwa $w$ erze globalizmu, Warsaw 2011] indicating the following publications: $\mathrm{P}$. Kuzior, Transgraniczna przestępczość zorganizowana - asymetryczne zagrożenie, „Prawo Europejskie w Praktyce”, 2008 nr 12 (54), M. Madej, Zagrożenia asymetryczne państw obszaru transatlantyckiego, Warsaw 2007. 
times by representatives of science. They resulted in creating numerous non-legal, mostly criminological definitions. None of them has gained a common approval ${ }^{2}$.

For instance, H. D. Schwind says that organized crime is a social process that meets the following criteria ${ }^{3}$ :

1) satisfying the needs of a part of the society for illegal services,

2) planning specific types of criminal business including risk of detection and punishing, amount of labour, as well as costs and profits,

3) generating other kinds of crime ("organized crime is the core of crime, around which its other types are created"),

4) durability of a criminal group exceeding periods of life of particular members, a group having its own interests,

5) strategic and tactical planning, rational operation, division of roles, specialty,

6) compliance with standards of a subculture, in particular loyalty towards the group,

7) enforcement of compliance with group norms, by using violence, but as ultima ratio (and consequently more often the threat of using violence is used more often),

8) pursuit of conducting also legal business activities for the purpose of concealing criminal activity, including the so-called money laundering,

9) use of assistance of protectors and advisors from among representatives of prosecution and judiciary bodies, political authorities, business institutions, palestrae,

10) international nature and superregional linkages.

In the Polish science of penal law, among others, a view was expressed, according to which the perspectives with such a high degree of detail, extremely valuable on the grounds of criminology, in practice entails several unsolvable problems ${ }^{4}$. Above all, it is difficult to give them a universal character; for instance "durability of a criminal

2 See e.g.: E. Pływaczewski, Przestępczość zorganizowana i jej zwalczanie w Europie Zachodniej (ze szczególnym uwzględnieniem Republiki Federalnej Niemiec), Warsaw 1992, s. 21- 25, B. Hołyst, Przestępczość zorganizowana w Polsce, „Acta Universitatis Lodziensis Folia Iuridicia” 63, 1995, p. 3-5, A. Marek, Przestępczość zorganizowana. Zarys problematyki, in: Kryminologiczne i prawne aspekty przestępczości zorganizowanej. Studies and materials, [ed:] A. Marek, W. Pływaczewski, Szczytno 1992, p. 24-26, 29-32, H.J. Schneider, Przestępczość zorganizowana z międzynarodowego kryminologicznego punktu widzenia (lecture given at the European Postgraduate Study of the Issues of Crime of the University of Łódź at the Munster University in July 1995), „Prokuratura i Prawo” 1995, nr 10, p. 7-12, R. Filipiuk, W. Jasiński, Przestępczość zorganizowana i jej zwalczanie w Republice Federalnej Niemiec. Sprawozdanie ze szkolenia przeprowadzonego przez policjantów Federalnego Urzędu Kryminalnego, „Przegląd Policyjny” 1995, no. 1-2, p. 88-90.

3 Przestępczość zorganizowana z międzynarodowego kryminologicznego punktu widzenia, op. cit., p. 8-12.

4 C. Sońta, Ugrupowania przestępne z art. 258 k.k. jako wyznacznik zorganizowanej przestępczości, op. cit. 
group exceeding periods of life of particular members" is actually characterized by numerous criminal organizations, but excludes from the scope of the definition those of them which are characterized by much lower durability 5 . Similarly, "international nature and superregional linkages" are characteristics of cross-border criminal organizations, but many other criminal organizations do not meet this requirement due to a limited territorial scope of activities ${ }^{6}$.

In this context, it is proposed to adopt a perspective different from criminological definitions in which organized crime should be understood as all crimes committed within the criminal structures that are characterized by organization ${ }^{7}$. Juridical (normative) types of such groups in the Polish law are stipulated by Article 258 (and Article 65 ) of the Penal Code ${ }^{8}$. These provisions describe an organized group and association aimed to commit a fiscal offence. For this reason, determining the scope of the notion of "organized crime", we should refer to the hallmarks of organizing an association or a group specified in Article 258 and Article 65 of the Penal Code 9 . On the other hand, crimes committed even by many perpetrators, but operating under an agreement without an element of organization or a criminal group without this element, are not within the notion of organized crime due to the lack of organization of perpetrators ${ }^{10}$.

Organized crime takes diverse form, depending on the regions of presence, the sphere of activity of the perpetrators, or qualitative differences with regard to the level (quality) of organization ${ }^{11}$. Those of them that achieve the highest level of organization and functioning, are defined as associations of mafia nature or simply mafias ${ }^{12}$.

In the opinion of P. Pezzino it is difficult to clearly determine the source of origin of the term "mafia"; it can be sought it the Italian Piemont where, at the end of the

5 Ibidem.

6 As above.

7 C. Sońta, Ugrupowania przestępne z art. 258 k.k. jako wyznacznik zorganizowanej przestępczości, op. cit.

8 i.e. of the Act of 6 June 1997 - Penal Code; "Journal of Laws" no. 88, item 553 as amended.

9 C. Sońta, Ugrupowania przestępne z art. 258 k.k. jako wyznacznik zorganizowanej przestępczości, op. cit. Similarly: J. Wojciechowski, Ustawa o ochronie obrotu gospodarczego z komentarzem, Warsaw 1994, p. 34.

10 C. Sońta, Ugrupowania przestępne z art. 258 k.k. jako wyznacznik zorganizowanej przestępczości, op. cit.

11 E.g.: B. Hołyst, Przestępczość zorganizowana w Polsce, „Acta Universitatis Lodziensis Folia Iuridicia” 63, 1995, E. Pływaczewski, Możliwości statystycznego ujęcia przestępczości zorganizowanej na przykładzie doświadczeń niemieckich, „Przegląd Policyjny” 1994, no. 1, C. Sońta, Zorganizowana grupa i związek przestępny we wspótczesnym polskim prawie karnym na tle teorii i orzecznictwa - zarys problematyki. Część I, „Wojskowy Przegląd Prawniczy” 1997 no. 1, Ugrupowania przestępcze $z$ art. 258 k.k. jako wyznacznik zorganizowanej przestępczości, op. cit.

12 See: E. Pływaczewski, Przestępczość zorganizowana i jej zwalczanie (...), op. cit., s. 14, 10, C. Sońta, Zorganizowana grupa i związek przestępny we współczesnym polskim prawie karnym na tle teorii $i$ orzecznictwa - zarys problematyki, op. cit. 
19th century, a mafia became a synonym of Camorra. ${ }^{13}$ It is commonly assumed that there are 5 Italian mafia organizations that have been formed in different regions of the country ${ }^{14}$. All of them are suspected of conducting criminal activities worldwide; probably, their representatives are present in many countries of Europe and other continents ${ }^{15}$. The Sicilian mafia was established obviously on Sicily, Camorra originates from Naples, and the Calabrian mafia - from the mountainous region of Calabria ${ }^{16}$. Sacra Corona Unita is the youngest Italian mafia, originating from the region of Puglia, while Cosa Nostra - the American mafia (strictly speaking: created in the United States by citizens of this country and immigrants from Italy) - comes partially from the Sicillian mafia and other Italian organizations and from the very beginning of its existence, it has been characterized by a specific ethnic composition ${ }^{17}$.

Mafia is, on the one hand, a proper name of a Sicillian criminal organization, which has been used in the sense at least since the 19 th century ${ }^{18}$. In time, this name started to be used also in the second meaning - for each criminal organization of mafia nature ${ }^{19}$. The name of mafia is sometimes used for a specific method and way of conduct, and moreover - clearly incorrectly - for primitive criminal groups ${ }^{20}$. It is also possible to encounter reference of this term to informal political structures whose members use specific methods of political fight ${ }^{21}$.

Analysis of Polish and foreign criminal organizations and scientific literature devoted to them indicates that the mafia nature of such an organization should be spoken of when it is characterised by the highest level of organization that, in addition, enables:

- money laundering,

- investments in the sphere of lawful business transactions,

- influencing the activities of authorities and public administration, including prosecution and judiciary bodies 22 .

In the Polish reality, like in most legislations, the notion of mafia has no legal meaning, only criminological, forensic and political.

\footnotetext{
13 See P. Pezzino, La nuova Italia, Diabassis, Florence 1995, p. 45.

14 www.howstuffworks.com

15 Ibidem.

16 Ibidem.

17 As above.

18 See: G. Gellert, transl. by M. Schweinitz-Kulisiewicz, Mafia, Warsaw 1984, p. 10, C. Sterling, transl. by J. Mikos, Mafia. Sycylia rządzi światem, Warsaw 1992, p. 42, J. Boucek, transl. by E. and W. Kaniewski, Ośmiornica - Historia sycylijskiej mafii, Gdańsk 1992, p. 26.

${ }^{19}$ E. Pływaczewski, Przestępczość zorganizowana i jej zwalczanie (...), op. cit., p. 14, 10.

20 Ibidem, p. 14.

${ }^{21} \mathrm{~J}$. Kossecki, Tajemnice mafii politycznych, Kielce 1991. See: C. Sońta, Zorganizowana grupa i związek przestępczy we współczesnym polskim prawie karnym na tle teorii i orzecznictwa, op. cit.

22 C. Sońta, Ugrupowania przestępne z art. 258 k.k. jako wyznacznik zorganizowanej przestępczości, op. cit.
} 


\section{Basics of the Italian antimafia law}

Growing inconvenience of the activities of mafia organizations was counteracted, in the 1980s, with gradually more and more radical measures of reaction of the Italian states, including measures of legal and penal nature.

In Parliament Antimafia Commission and the Italian Parliament have developed the antimafia law - the Ragnoni-La Torre Act, which introduced changes in the Italian penal law, adding Article 416-bis of the Penal Code, penalizing affiliation to associations of mafia nature. This change resulted in penalty of a person given the status of a mafioso and began to cause forfeiture of property of a such person subject to legal regulation ${ }^{23}$.

On the other hand, article 74 of the decree of the President of the Republic of Italy no. 309 of 9.10 .1990 criminalizes participation in an association of three or more people intended to commit crimes consisting in illegal trade in narcotic or psychotropic substances. Circumstances qualifying penal liability include, among others, establishing, managing, funding such an organization, its armed character (understood similarly as pursuant to Article 416 bis of the Italian Penal Code) and the number of participants greater than or equal to ten ${ }^{24}$. Apart from introduction of a wide range of qualifying circumstances, this regulation is distinguished by the very identification of special purpose of the group.

The use of pentito structure, as a means to combat organized crime, a new and promising measure as an antimafia instrument, broke an unrivalled, compact world of organized criminals down into groups and associations that were diverse in terms of experience, the region of operations and the scope of impact on the local community. The pentito structure has become an effective instrument to break the conspiracy of silence, the so-called omerta. The procedure of introduction of the pentito institution made it possible finally take control over the world of organized crime in Italy. The prosecution bodies gradually acquired, in the course of trials of repentant criminals, detailed, previously protected knowledge about the criminal world, the method of operation of a mafia, and ultimately breaking the hermetic clans of organized criminals ${ }^{25}$.

The local mechanisms of combating organized crime turn to a model of creating the standards of administrative and civil law, to principles of functioning of

23 C. Sterling, Mafia. Sycylia rzadzi światem, Warsaw 1992, p. 57 and next; C. Lucarelli, La mattanza, Torino 2003, p. 20 and next; N. Mancuso, La legislazione antimafia ed i rapporti di diritto pubblico, La legge antimafia tre anni dopo: bilancio di un'esperienza applicativa, [ed:] G. Fiandaca, Milano 1986; J. Brylak, A. Gilardini, R. Privitera, Instytucja świadka koronnego w systemie włoskiego prawa karnego procesowego, „Prokuratura i Prawo” 2005, no. 11, p. 104 and next.

24 See: R. Rychlik, Zarys włoskiej koncepcji walki z przestępczościa zorganizowana, „Prokuratura i Prawo" 1998, no. 6, p. 147.

25 C. Ruga Riva, Il premio per la collaborazione processuale, Milano 2002. 
local government units, economic law, public procurement law and environmental protection law. Ratio legis of these solutions consists in pursuing protection of those areas of public life, preventing exposure to infiltration by organized crime. The Italian legislator thus introduced solutions of purely preventive nature. Such solutions are not surprising when we look at these issues as a significant part of the history of Italian legislation and a certain typical model of drawing conclusions about law-making processes in the penal trial law system, forced by a specific nature of the Italian community.

Probably long-term existence of organized crime in Italy facilitated collecting experiences of the Italian judiciary system and community for solutions used until today. Effectiveness, for a long time, of the Act on a crown witness made it possible to verify the theory in practice, introduce corrections best corresponding to the needs of the changing reality. It seems that the Italian legal system has irretrievably gone out of the period of legislative trials, failures with regard to the crown witness institution.

The criminal policy of the state should cross the boundaries, also cultural and internal ones. A factor of tremendous importance for extending the spectrum of perception of various, alternative legal structures is comparative law and observation of their effectiveness of operation. Italy, perceived as a country exporting the methods of awarding bonuses to perpetrators draw attention to the sustained losses of the judiciary system, therefore new solutions are much appreciated.

Messages provided by pentitio obtain the status of testimonies, therefore the trial role of pentito is close to the witness. The theorists, introducing the notion of "testimony", did not determine the definition of this concept. Lexically, it means an official court statement, facts testified by somebody in a given case. In the trial perspective a testimony is defined as evidence coming from a witness. At the same time, the crown witness is deprived of virtually all rights guaranteed to a typical witness by the code of criminal procedure.

\section{Penality of participation in association of mafia nature in the penal code of the republic of Italy}

From the proper name of one of the Italian criminal organizations comes, as it has already been mentioned, the term "mafia", commonly used to identify any criminal organization with the highest degree of organization and functioning. For this reason, it seems understandable that the Penal Code of the Republic of Italy contains a solution which is original, as apart from a "normal" criminal association (Article 41626) it introduces the term of association of mafia nature (Article 416

${ }^{26}$ „Quando tre o piu' persone si associanoallo scopo di commettere piu delitti, coloro che promuovono o costituiscono od organizzano l'associazione sono puniti, per cio' solo, con la reclusione da tre a sette anni (32 quater, 305). Per il solo fatto di partecipare all'associazione (270, 305, 306, 309), 
bis $\left.^{27}\right)$. It consists in the fact that at least 3 people comprising it use fear caused by mafia linkages and the resulting subordination and conspiracy of silence for the following purposes:

- committing crimes,

- taking over (both directly and indirectly) control over business, licenses, permits, tenders and public procurement - in order to bring unjustified material benefit to oneself or to someone else,

- preventing or hindering free voting or ensuring votes for oneself or someone else during elections for representative public authorities.

In this regulation attention is drawn, apart from giving a normative meaning to the notion of mafia, to classifying, into statutory features of crime, casuistically described methods of operation and goals typical of criminal structures with high degree of organization, which for at least a century have been developing their activities in Italy.

la pena e' della reclusione da uno a cinque anni.I capi soggiacciono alla stessa pena stabilita per i promotori. Se gli associati scorrono in armi (585) le campagne o le pubbliche vie si applica la reclusione da cinque a quindici anni $(270,305,306)$. La pena e' aumentata (64) se il numero degli associati e' di dieci o piu' (417)." Przyt. after: I nuovi codice penale e codice di procedura penale, Annotazioni e coordinamenti a cura di L. Alibrandi (per il codice penale), P. Corso (per il codice di procedura penale), Casa Editrice La Tribuna - Piacenza 1991. See also art. 417, 418.

27 „Chiunque fa parte di un'associazione di tipo mafioso formata da tre o piu' persone, e punito con la reclusione da tre a sei anni. Coloro che promuovono dirigono o organizzano l'associazione (416) sono puniti, per cio' solo, con la reclusione da quatro a nove anni. L'associazione e' di tipo mafioso quando coloro che ne fanno parte si avvalgono della forza di intimidazione del vincolo associativo e della condizione di assoggettamento e di omerta ' che ne deriva per commettere delitti, per acquisire in modo diretto o indiretto la gestione o comunque il controllo di attivita' economiche, di concessioni, di autorizzazioni, appalti e servisi publici o per realizzare profitti o vantaggi ingiusti per se' o per altri. Se l'associazione e' armata si applica la pena della reclusione da quatro a dieci anni nei casi previsti dal primo comma e da cinque a quindici anni nei casi previsti dal secondo comma. L'associazione si considera armata quando i partecipanti hanno la disponibilita', per il conseguimento dlella finalita' dell'associazione, di armi o materie esplodenti (585), anche se occultate o tenute in luogo di deposito. Se le attivita' economiche di cui gli associati intendono assumere o mantenere il controllo sono finanziate in tutto o in parte con il prezzo, il prodotto, o il profitto di delitti, le pene stabilite nei commi precedenti sono aumentate da un terzo alla meta'. Nei confronti del condannato e' sempre obligatoria la confisca delle cose che servirono o furono destinate a commetere il reato e delle cose che ne sono il prezzo, il prodotto, il profitto o che ne costituiscono l'impiego (240). Le dispozizioni del presente articolo si applicano anche alla camorra e alle altre associazioni , comunque localmente denominate, che valendosi della forza intimidatrice del vincolo associativo persequono scopi corrispondenti a quelli delle associazioni di tipo mafioso." Kolejne jednostki redakcyjne mają następujące brzmienie: „417. Nel caso di condanna per i delitti preveduti dai due articoli precedenti r' sempre ordinata una misura di sicurezza $(215,288 ; 658$, c.p.p.).

418. Chiunque, fuori dei casi di consorso nel reato (110) o di favorieggiamento $(378,379)$, da' rifugio o fornisce il vitto a taluna delle persone che partecipano all'associazione (416, 416 bis) e' punito con la reclusione fino a due anni. La pena e aumentata (64) se il rifugio o il vitto sono prestati continuamente. Non e' punibile chi commette il fatto in favore di un prossimo congiunto (307).” Quot. after: I nuovi codice penale..., op. cit. 
Apart from the definition in a mafia association, Article 416 bis of the Italian Penal Code corresponds to the Polish equivalent (Article 258 of the Penal Code) not only by stipulating liability on the basis of delictum sui generis for the very participation in an association, but also because it envisages qualified types of this crime in the form of establishing or manage an association as well as participation in this association when it has an armed nature. At the same time, a provision of the Italian Penal Code also defines an armed nature of a mafia association; this hallmark is fulfilled, if members of a group have weapons or explosives for pursuing its goals, regardless of the place of storage of these means. In addition, a circumstance qualifying liability is funding a company selected by a group for takeover from the funds coming directly or indirectly from crime, and Article 416 bis envisages obligatory forfeiture, in the case of sentencing for crimes provided in it, the means of crime and objects coming directly or indirectly from it.

The issue of interpretation of features of a criminal association of mafia nature was undertaken by the Italian cessation court, for instance, in rulings of 17.09.1987, no. 9859 and of 22.12 .1987 , no. $13070^{28}$. In the former of the rulings this court recognized that for the existence of a mafia association it is not sufficient for its members to use violence or threat in order to intimidate other persons, but a necessary factor is that this force of intimidation should result from the internal bond and serve generating such mechanisms of forcing submission that hinder detection and prosecution of committed crimes, as well as will propagate conspiracy of silence. In the latter of the rulings, the raised problem was the criterion of participation in a mafia association, stating that its member is a person who undertakes actions, even of subordinate meaning, bringing benefit to an association, and does this inside the organization, and not accidentally. Moreover, a subjective condition was raised - so that the perpetrator undertook activity with intent to associate in order to execute the association's program, although direct achievement of this goal is not required.

The essence of participation in a criminal association in the light of Italian law comes down to determination of affiliation, association or impact on other persons by committing crimes of collective nature. The perpetrator is responsible not only for the result of his or her criminal action, but also for the very participation, if it is confirmed by evidence. The Italian law specially regulates liability for committing crimes within the criminal organization. The perpetrator operating in such a structure bears not only more strict liability, but is also liable for the very participation in it. A feature of a criminal group is organization, principles of accepting members, a feature of subordination and discipline, agreed scopes of competences associated in a stricter manner with the outlined program of operation. A criminal association

${ }^{28}$ W. Smardzewski, Kilka uwag o włoskiej przestępczości zorganizowanej i roli „pentito” w jej zwalczaniu, „Prokuratura i Prawo” 1995, no. 1, p. 72. 
is also characterized by separation of permanent management within the framework of organizational structure, and identification of sanctions related to refusal to perform the order or, for example, cooperation with a competitive criminal group, independent functioning or cooperation with judiciary bodies ${ }^{29}$.

An organized group or association have armed nature, if they have and use firearm or their activities substantially involves use of weapons. For liability of the perpetrator it is not important for him or her to have weapons, the sufficient fact is awareness that other participants of an organized group or association have or use weapons.

Participation in an organized criminal group belongs to the group of crimes against the public order that breach the proper functioning of the state and directly threaten security of citizens. On the grounds of the Polish penal law, participation in an association or an organized group, intended to commit a fiscal offence, is punishable. An organized criminal group is a team of at least three people aiming at committing a crime or crimes. A criminal group does not need to have a long-term action program - as it is in the case of a criminal association, however, it has some elements of an organization - in particular, agreed management and division of roles.

\section{LITERATURE:}

1. J. BouceK, transl. by E. and W. Kaniewski, Ośmiornica - Historia sycylijskiej mafii, Gdańsk 1992.

2. J. Brylak, A. Gilardini, R. Privitera, Instytucja świadka koronnego w systemie wloskiego prawa karnego procesowego, „Prokuratura i Prawo” 2005, no. 11.

3. R. FillipiuK, W. JASIŃSKI, Przesteppzość zorganizowana i jej zwalczanie w Republice Federalnej Niemiec. Sprawozdanie ze szkolenia przeprowadzonego przez policjantów Federalnego Urzędu Kryminalnego, „Przegląd Policyjny” 1995, no. 1-2.

4. G. Gellert, transl. by M. Schweinitz-Kulisiewicz, Mafia, Warsaw 1984.

5. B. НоŁYsт, Przestępczość zorganizowana w Polsce, „Acta Universitatis Lodziensis Folia Iuridicia” 63, 1995.

6. J. Kossecki, Tajemnice mafii politycznych, Kielce 1991.

7. P. KuzIOR, Transgraniczna przestępczość zorganizowana - asymetryczne zagrożenie, „Prawo Europejskie w Praktyce”, 2008 no. 12 (54).

8. C. LuCarelli, La mattanza, Torino 2003.

9. M. MADEJ, Zagrożenia asymetryczne państw obszaru transatlantyckiego, Warsaw 2007.

10. N. MAncuso, La legislazione antimafia ed i rapporti di diritto pubblico, La legge antimafia tre anni dopo: bilancio di un'esperienza applicativa, ed.: G. Fiandaca, Milano 1986.

11. A. Marek, Przestępczość zorganizowana. Zarys problematyki, in: Kryminologiczne i prawne aspekty przestępczości zorganizowanej. Studies and materials, [ed:] A. Marek, W. Pływaczewski, Szczytno 1992.

29 See N. Marino, Sangue e appalti, Mafia, politica, affari: rapporto 1992, Palermo 1992, p. 110 and next. 
12. N. MARino, Sangue e appalti, Mafia, politica, affari: rapporto 1992, Palermo 1992.

13. P. Pezzino, La nuova Italia, Diabassis, Florence 1995.

14. E. PŁYWACZEWSKI, Możliwości statystycznego ujęcia przestępczości zorganizowanej na przykładzie doświadczeń niemieckich, „Przegląd Policyjny” 1994, no. 1.

15. E. PŁYWACZEWSKI, Przestępczość zorganizowana i jej zwalczanie w Europie Zachodniej (ze szczególnym uwzględnieniem Republiki Federalnej Niemiec), Warsaw 1992.

16. C. Ruga Riva, Il premio per la collaborazione processuale, Milano 2002.

17. R. RYchlik, Zarys włoskiej koncepcji walki z przestęczościa zorganizowana, „Prokuratura i Prawo" 1998, no. 6.

18. H.J. SchNeIDER, Przestępczość zorganizowana z międzynarodowego kryminologicznego punktu widzenia (lecture at the European Postgraduate Study of the Issues of Crime of the University of Łódź at the Munster University in July 1995), "Prokuratura i Prawo" 1995, no. 10.

19. H.D. Schwind, Definition und Geschichte der organisierten Kriminalitaet in kurzen Ueberblick, in: ed.: H.D. Schwind, G. Steinhilper, E. Kube, Organisierte Kriminalitaet, Heidelberg 1987.

20. W. SMARDZEwski, Kilka uwag o włoskiej przestępczości zorganizowanej i roli „pentito” w jej zwalczaniu, „Prokuratura i Prawo” 1995, no. 1.

21. C. SońtA, Ugrupowania przestępne z art. 258 k.k. jako wyznacznik zorganizowanej przestępczości, in: (ed.:) R. Jakubczak, R. Radziejewski, Terroryzm a bezpieczeństwo państwa w erze globalizmu, Warsaw 2011.

22. C. SoŃTA, Zorganizowana grupa i zwiąek przestępny we współczesnym polskim prawie karnym na tle teorii i orzecznictwa-zarys problematyki. Część I, „Wojskowy Przegląd Prawniczy" 1997, no. 1.

23. C. Sterling, transl. by J. Mikos, Mafia. Sycylia rzadzi światem, Warsaw 1992.

24. www.howstuffworks.com

\section{MAFIA WE WEOSKIM KODEKSIE KARNYM}

Streszczenie: W naukach o bezpieczeństwie zorganizowana przestępczość zaczyna być traktowana jako zagrożenie asymetryczne. Przestępczość zorganizowana to, zdaniem Autorów, ogół przestępstw popełnianych w ramach struktur przestępczych, które charakteryzują się zorganizowaniem. Mafia to, $\mathrm{z}$ jednej strony, nazwa własna sycylijskiej organizacji przestępczej, która jest używana w tym znaczeniu co najmniej od XIX wieku. Z drugiej strony oznacza ona również każdą przestępczą organizację o charakterze mafijnym. W prawie polskim, podobnie jak w większości ustawodawstw, pojęcie mafii nie występuje. Autorzy próbują jednak stworzyć jej definicję pozaprawną. Zwracają uwagę, że kodeks karny Republiki Włoch zawiera oryginalne rozwiązanie - oprócz „zwykłego” związku (stowarzyszenia) przestępczego (art. 416) wprowadza karalność udziału w związku (stowarzyszeniu) o charakterze mafijnym (art. 416 bis). Głównym celem niniejszego opracowania jest analiza tej konstrukcji na tle genezy i rozwiązań włoskiego prawa antymafijnego.

Słowa kluczowe: Mafia, organizacje przestępcze, prawo kryminalne, Włochy, przestępczość zorganizowana. 